\title{
The Canadian Entomologist
}

\begin{tabular}{lll}
\hline \hline Vol. 115 & Ottawa, Canada, July 1983 & No. 7 \\
\hline \hline
\end{tabular}

\section{PHENOLOGY OF THE SAN JOSE SCALE (HOMOPTERA: DIASPIDIDAE) IN NEW YORK STATE APPLE ORCHARDS ${ }^{1,2}$}

\author{
Diane L. Mague ${ }^{3}$ and W. HaRvey Reissig \\ New York State Agricultural Experiment Station, Geneva, New York 14456
}

\begin{abstract}
Can. Ent. 115: 717-722 (1983)

Pheromone trapping studies from 1979 to 1981 showed that there were two periods of San Jose scale, Quadraspidiotus perniciosus (Comstock), male flight activity annually in western New York apple orchards. Spring flight, which resulted from overwintering black caps, began at ca. 94-140 degree-days (base $10^{\circ} \mathrm{C}$ from 1 March) and occurred during bloom in the apple varieties studied. First generation crawlers emerged at ca. 360 degree-days. Second generation crawlers emerged at ca. 890 degree-days and were active throughout September. Regression analyses showed a logistic relationship between crawler density and fruit infestation, and inverse linear relationships between pheromone trap catches and San Jose scale infestation levels within trees.
\end{abstract}

\section{Résumé}

Des études de piégeage à la phéromone effectuées de 1979 à 1981 ont révélé 2 périodes annuelles de vol des mâles au pou de San José, Quadraspidiotus perniciosus (Comstock), dans les vergers de l'ouest de New York. Le vol de printemps originant du stade hivernant a commencé à environ $94-140$ degrés-jours (base $10^{\circ} \mathrm{C}$ à partir du 1 mars) et s'est produit durant la floraison des variétés étudiées. Les larves errantes de la première génération ont émergé à environ 360 degrés-jours. Les larves errantes de la seconde génération ont émergé à environ 890 degrés-jours, et sont restées active durant tout le mois de septembre. Des analyses de régression ont révélé une relation logistique entre la densité des larves errantes et l'infestation des fruits, ainsi que des relations linéaires inverses entre les nombres capturés au piège à phéromone et les niveaux d'infestion intra-arbres.

\section{Introduction}

In recent years, outbreaks of the San Jose scale, Quadraspidiotus perniciosus (Comstock), in many apple-growing regions of New York State have resulted in an increased need to incorporate controls for this pest into orchard management programs. Control strategies for San Jose scale include dormant pruning of infested wood, application of a pre-bloom oil, and post-bloom insecticidal treatments. The effectiveness of summer control programs depends upon appropriate timing of sprays based on adult male flight and subsequent periods of crawler activity. The discovery (Rice 1974) and identification (Gieselmann et al. 1979) of a female-produced sex pheromone in San Jose scale have resulted in the use of pheromone traps to detect and monitor adult male flight activity. Male phenology in the western United States has been determined by pheromone trapping studies (Rice and Jones 1977; Rice and Hoyt 1980). These studies were used in the development of a Predictive Extension Timing Estimator (PETE) model (Welch et al. 1978) for scale (Jorgensen et al. 1981), that simulates male flight activity and estimates crawler emergence based on degree-day $\left({ }^{\circ} \mathrm{D}\right)$ accumulations. The future use of such predictive

\footnotetext{
${ }^{1}$ Approved by the Director of the New York State Agricultural Experiment Station as Journal Paper No. 3430. ${ }^{2}$ Submitted by the senior author in partial fulfillment of requirements for the Ph.D. degree at Cornell University, Ithaca, New
York. ${ }^{3}$ Present address: E. I. du Pont de Nemours \& Co., Biochemicals Dept., Experimental Station, Bldg. 335, Wilmington, Dela-
ware 19898.
} 
models for timing controls in the Northeast will depend on the collection of phenological data for model validation for this region.

The objective of this study was to determine the seasonal flight activity of male San Jose scale in New York and to relate trap catch to levels of scale infestation within trees. Seasonal crawler abundance was also monitored to describe crawler phenology and to investigate the relationship between crawler density and fruit infestation.

\section{Materials and Methods}

Male flight. Male flight activity from 1979 to 1981 in western New York was monitored using pheromone traps. In 1979, studies were conducted in three scale-infested apple orchards growing on seedling rootstock: a 30-year-old, 5-ha, untreated, commercial Baldwin cv. block in Sodus (Wayne County), NY; a 20-year-old, 3-ha, treated, commercial McIntosh cv. block in Lyons (Wayne County), NY; and a 50-year-old, abandoned, 0.5ha block of Yellow Transparent cv., also in Lyons. At each site, a pheromone trap was placed $1.5 \mathrm{~m}$ above the ground within the canopies of three randomly selected trees that were at least $100 \mathrm{~m}$ apart. Traps were constructed from $3 \mathrm{M}$ Sectar ${ }^{\circledR}$ (3M Co., St-Paul, Mn 55101) traps that had been cut in half horizontally to form a tent-type trap. A plastic strip was attached between the bottom flaps of each trap to hold the sticky trapping surfaces apart at a 60-degree angle. Each trap was baited with $100 \mu \mathrm{g}$ of 3-methylene-7-methyl-7octen-1-yl propanoate (SJS-2) (Gieselmann et al. 1979) applied to a rubber septum. Septa were suspended on wires from the center top fold inside the traps and replaced every 4 weeks. Trap catch of males was recorded at least twice each week at each site from 22 May through 12 September.

During 1980, in Phelps (Ontario County), NY, males were trapped from 5 May to 14 October in 14 nonadjacent, 10-year-old, untreated apple trees (cv. Wayne) on M.9 rootstocks. Trees in this 0.5 -ha block were ca. $2.5 \mathrm{~m}$ in height and $5 \mathrm{~m}$ apart. In 1981 , males were trapped from 19 May to 30 September in a 3-ha block of 35-year-old Rhode Island Greening cv. trees growing on seedling rootstock ( $4.5 \mathrm{~m}$ in height) in Sodus, NY. Traps were located in 10 scale-infested trees which were set at $7.6 \times 7.6 \mathrm{~m}$ spacings. This orchard had received insecticidal treatments in previous years. Both of these tests used standard San Jose scale pheromone traps supplied by Zoecon (Zoecon Corp., Palo Alto, CA 94304) that were baited with septa loaded with SJS-2 $(300 \mu \mathrm{g})$. One trap was placed $1.5 \mathrm{~m}$ from the ground in the southern canopy of each tree. Trap catch was recorded 3 times each week and septa were replaced every 4 weeks. Mean trap catch for each year was plotted over seasonal ${ }^{\circ} \mathrm{D}$ accumulations (Baskerville and Emin 1969) above a base of $10^{\circ} \mathrm{C}$ from 1 March.

Crawlers. In 1980, seasonal crawler abundance was assessed in the Wayne block where male flight was monitored. Crawlers were sampled in 14 trees bearing sufficient fruit to allow later comparison of fruit infestation with crawler density. Nine trees in this group also contained scale pheromone traps. After the onset of male flight, trees were examined daily to detect first crawler emergence. Then, crawlers were sampled each week through 16 September.

Crawlers on the bark were sampled using a piece of cardboard from which a $10-\mathrm{cm}^{2}$ section had been removed. On each sampling date, the cardboard was placed over 10 randomly selected areas of bark on limbs $(>1 \mathrm{~cm}$ diam.) of each of the 14 trees. Active crawlers within the open $10-\mathrm{cm}^{2}$ area were counted with a hand lens. All direct counts were conducted prior to $1200 \mathrm{~h}$ on sunny days, since crawler emergence was greatest under these conditions (Mague 1982). On 16 September, the percentage of scale-infested fruit was evaluated in random samples of 20 fruit from each tree where crawlers had been sampled during the season. Regression analyses were performed to determine the re- 
lationships between seasonal totals of crawlers, crop infestation, and males trapped within each tree.

Crawler abundance was also estimated by direct counts during 1981 in four scaleinfested Rhode Island Greening cv. trees used in the male trapping study in Sodus, NY. However, since this planting was composed of mature, standard size trees, the sample grid was increased to $100 \mathrm{~cm}^{2}$. On each of the four trees, eight randomly selected units of bark on limbs $>5 \mathrm{~cm}$ in diameter were sampled weekly from 17 June through 30 September. In both 1980 and 1981 , the mean number of crawlers $/ 10 \mathrm{~cm}^{2}$ bark was plotted over ${ }^{\circ} \mathrm{D}$ accumulations (Baskerville and Emin 1969) above a base of $10^{\circ} \mathrm{C}$ from 1 March.

During 1981, sticky electrical tape traps, developed in Washington (S. C. Hoyt, pers. comm.), were also used to monitor crawler abundance in the four trees sampled by direct count. These traps were constructed of electrical tape $(1.8 \mathrm{~cm}$ wide) wrapped tightly around the circumference of a tree branch. A band of petroleum jelly ( $5 \mathrm{~mm}$ wide) was applied around the circumference at the center of the tape so that crawlers walking from either direction became trapped in the grease. Four traps were placed in each of the four trees and the tapes were replaced weekly from 15 June to 30 September. Crawlers on the tapes were counted under a dissecting microscope in the laboratory. Since tape traps were of varying length due to differences in branch diameters, crawler counts were adjusted to number $/ \mathrm{cm}^{2}$ of tape.

\section{Results and Discussion}

Male flight. In western New York, there were two periods of male flight activity annually during 1979, 1980, and 1981 (Fig. 1). The first male flight, that resulted from overwintering black caps, corresponded to the "early emergence" pattern described for this species by Jorgensen et al. (1981). Except for 1979 when first male emergence was not recorded, the onset of the spring flight ranged from 94 to $140^{\circ} \mathrm{D}$ (base $10^{\circ} \mathrm{C}$ ). This compared favorably with the estimates by Jorgensen et al. (1981) of $<139$ to $180^{\circ} \mathrm{D}$ for early emerging males. The first flight, which began in mid-May, peaked abruptly and ended prior to $300{ }^{\circ} \mathrm{D}$.

In other areas, the application of insecticides against emerging males and receptive females in the spring has been effective in controlling San Jose scale (Downing and Logan 1977; Rice et al. 1979). However, in New York, spring flights during 1979 and 1980 coincided with bloom in the four apple varieties studied. In 1981, male flight began during bloom and continued for a few days past petal fall. These data suggested that petal-fall sprays cannot be used to control males and receptive females in most seasons in western New York orchards.

The emergence of first generation males during the second flight began during late July at ca. $667^{\circ} \mathrm{D}$ and continued through September. Approximately 527 to $573^{\circ} \mathrm{D}$ elapsed between first emergence of each flight in the field, which compared favorably with the mean developmental time of $584^{\circ} \mathrm{D}$ for laboratory-reared scale (Jorgensen et al. 1981). According to these estimates, a partial third male flight contributed to trap catch beyond $1,215^{\circ} \mathrm{D}$

Crawlers. There were two overlapping periods of crawler emergence in western New York during 1980 and 1981 (Fig. 2). Throughout the 1981 season, crawler abundance as assessed by direct counts on the bark showed high linear correlation $(r=0.93)$ with crawler catch using the more sensitive electrical tape trap technique. Tape traps are a more practical method of monitoring seasonal activity and relative abundance of crawlers in commercial orchards than direct counts, but further research is needed to relate tape trap catch of crawlers to fruit infestation levels.

In each year, crawlers emerged about $230^{\circ} \mathrm{D}$ following male flights and mating. Emergence of first generation crawlers began in mid to late June at ca. $360^{\circ} \mathrm{D}$ and peaked 

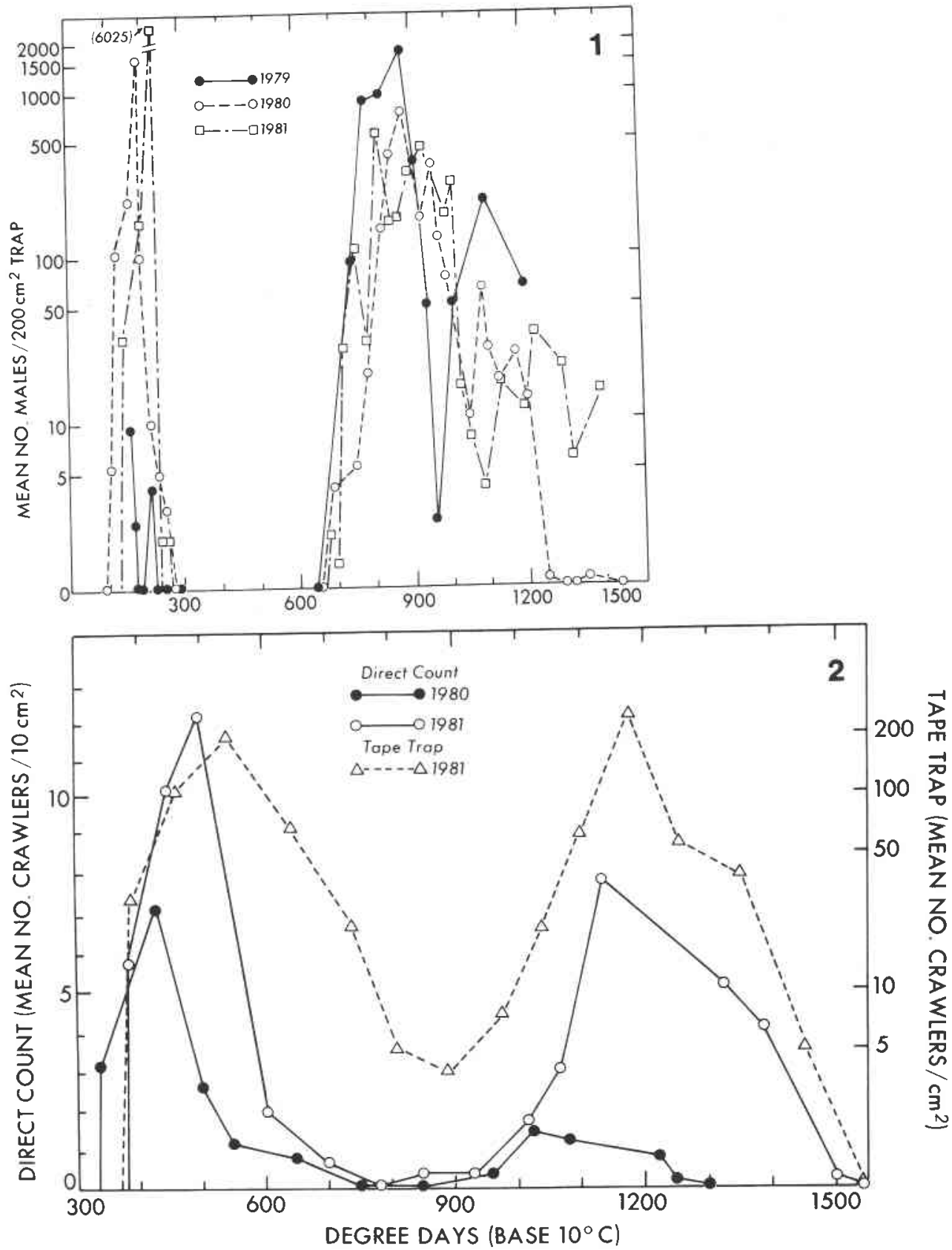

FIGS. 1-2. 1, male San Jose scale flight activity, 1979-1981. 2, San Jose scale crawler emergence, 1980 and 1981

within 10 days. Second generation emergence occurred at ca. $890^{\circ} \mathrm{D}$. Crawlers representing a partial third generation were probably included in samples past $1500^{\circ} \mathrm{D}$.

Infestation of the fruit by the crawlers began within the first week of their emergence in June and continued through harvest. In 1980, the relationship between seasonal totals of crawlers sampled/tree by direct counts and the resulting percentages of fruit infestation/ 

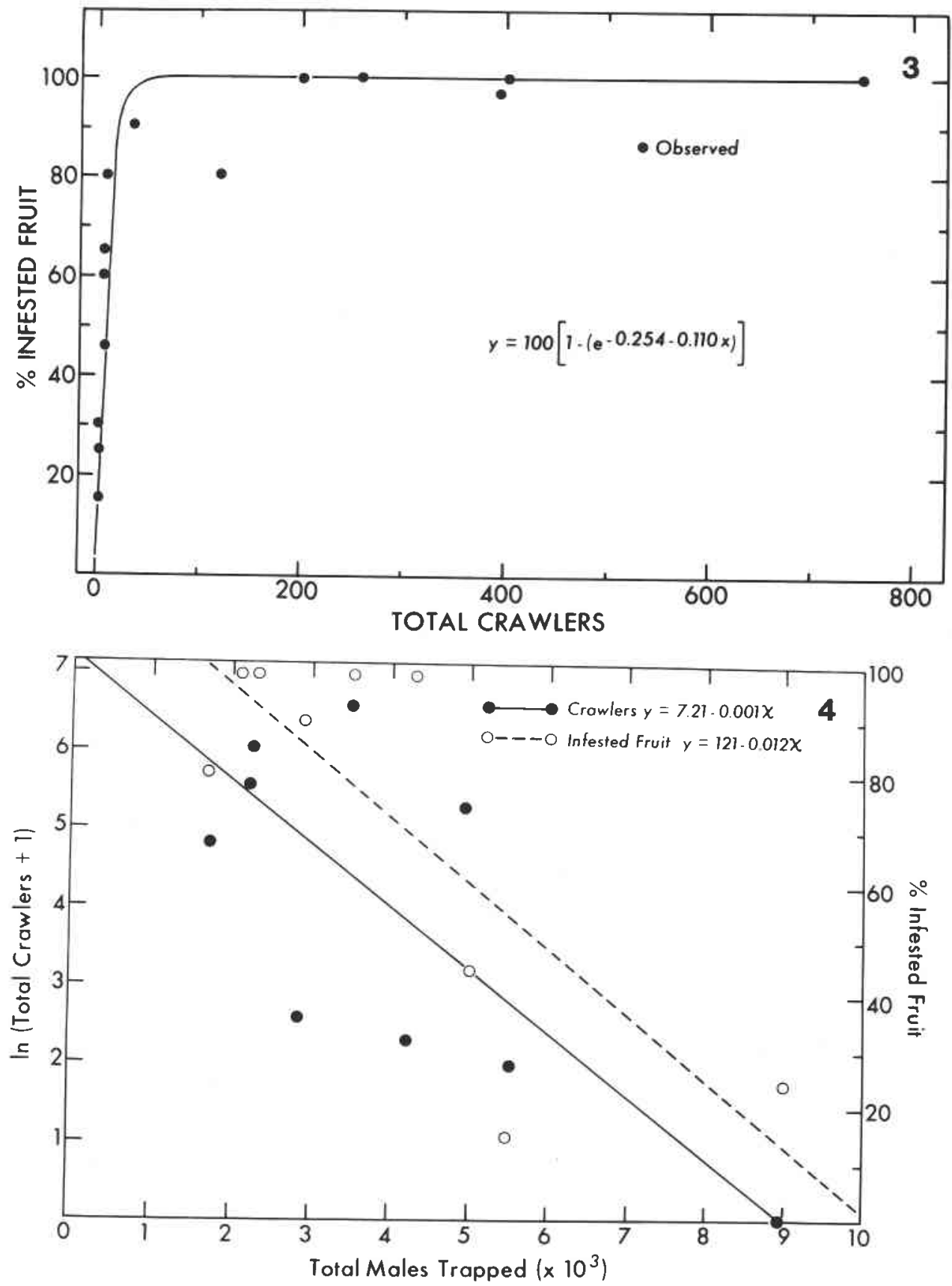

FIGS. 3-4. 3, relationship between total crawlers sampled/tree and percentage of infested fruit at harvest. 4, regression lines describing relationships between seasonal totals in male pheromone trap catch/tree $(X$-axis) and (1) the natural $\log$ (cumulative crawlers sampled +1 tree), and (2) percentages of infested fruit/tree at harvest ( $Y$-axes). 
tree at harvest was approximated by the Mitscherlich generalized logistic $\left(r^{2}=0.91\right)$ (Nelder 1962) (Fig. 3). Since San Jose scale densities in this orchard were high, this curve best described the relationship between crawlers and percentages of fruit infestation above acceptable limits of $<2 \%$ infested fruit. However, these data indicated that even relatively low numbers of crawlers can result in significant levels of crop damage. According to this relationship, fruit infestation reached $100 \%$ after cumulative direct counts exceeded about 66 crawlers/tree during the season. Crawler totals in excess of this number only contributed to increases in the number of scale/fruit.

Cumulative pheromone trap catch of males/tree was inversely related to both the natural $\log$ of direct count totals of crawlers $+1 /$ tree $\left(r^{2}=0.67\right)$ and the percent infested fruit/tree $\left(r^{2}=0.60\right)$ (Fig. 4). The trend for greatest pheromone trap catch in the least infested trees suggested that male flight between trees had occurred and supported other studies (Mague 1982) that showed that males could be trapped at least $22 \mathrm{~m}$ upwind from an infested orchard. These relationships may also indicate decreased ability of the pheromone trap to compete with females emitting natural pheromone closer to sites of male emergence on the bark at high population densities.

\section{Acknowledgments}

Thanks to H. Hebding and D. Hicks for their technical assistance, J. Barnard and B. Stanley for statistical advice, and R. McMillan for preparation of the figures. This research was in part funded by a Cohn Foundation grant.

\section{References}

Baskerville, G. L. and P. Emin. 1969. Rapid estimation of heat accumulation from maximum and minimum temperatures. Ecology 50: 514-517.

Downing, R. S. and D. M. Logan. 1977. A new approach to San Jose scale control (Hemiptera: Diaspididae). Can. Ent. 109: 1249-1252.

Gieselmann, M. J., R. E. Rice, R. A. Jones, and W. L. Roelofs. 1979. Sex pheromone of the San Jose scale. J. chem. Ecol. 5: 891-900.

Jorgensen, C. D., R. E. Rice, S. C. Hoyt, and P. W. Westigard. 1981. Phenology of the San Jose scale (Hompotera: Diaspididae). Can. Ent. 113: 149-159.

Mague, D. L. 1982. Biology of the San Jose scale (Quadraspidiotus perniciosus (Comstock) (Homoptera: Diaspididae)) in New York State apple orchards: Male flight phenology and crawler dispersal. Ph.D. Thesis, Cornell Univ., Ithaca, NY.

Nelder, J. A. 1962. An altemative form of generalized logistic equation. Biometrics 18: 614-616.

Rice, R. E. 1974. San Jose scale: Field studies with a sex pheromone. J. econ. Ent. 67: 561-562.

Rice, R. E. and S. C. Hoyt. 1980. Response of San Jose scale to natural and synthetic sex pheromones. Environ. Ent. 9: 190-194.

Rice, R. E. and R. A. Jones. 1977. Monitoring flight patterns of male San Jose scale (Homoptera: Diaspididae). Can. Ent. 109: 1403-1404.

Rice, R. E., S. C. Hoyt, and P. H. Westigard. 1979. Chemical control of male San Jose scale (Homoptera: Diaspididae) in apples, pears and peaches. Can. Ent. 111: 827-831.

Welch, S. M., B. A. Croft, J. F. Brunner, and M. F. Michels. 1978. PETE: an extension phenology modeling system for management of multi-species pest complex. Environ. Ent. 7: 487-494.

(Received 6 April 1982; accepted 2 September 1982) 